\title{
RENDANG LOKAN AS A CULINARY TOURISM ATTRACTION IN PESISIR SELATAN
}

\author{
Abdiani Khairat Nadra ${ }^{1}$, Efmilia Nora ${ }^{2}$ \\ 1,2Pogram Studi Usaha Perjalanan Wisata, Jurusan Administrasi Niaga, Politeknik Negeri \\ Padang, Indonesia \\ abdiani@pnp.ac.id ${ }^{1}$
}

\begin{abstract}
The tourism trend in which culinary tourism is one of the favorite tourist attractions that is favored provides opportunities for areas that have distinctive culinary delights, Pesisir Selatan is one of the areas that has traditional culinary specialties which if developed will become one of the tourist attractions. This study aims to see whether the culinary specialties of Pesisir Selatan Rendang Lokan has the potential to be developed as a tourist attraction. This research is descriptive with a qualitative approach, using Damanik and Weber's theory of uniqueness, originality, authenticity and diversity and is supported by Yoeti's theory of tourist attraction, namely having something to see, something to do and something to buy. Data collection was carried out by interview and observation. The results showed that Rendang Lokan has the potential to be developed as a tourist attraction. This can be seen from the uniqueness of its taste, its originality and consistency in the use of the same ingredients that has not changed since the past, its authenticity in the traditional manufacturing process, and its diversity on its flavors. As a tourist attraction, Rendang Lokan also meets the criteria of "Something to be seen" which is the process of making and processing ingredients and spices. It also has "Something to do" which is being able to involve tourists to join in cooking Rendang Lokan, and also "Something to buy" which acts as souvenir.
\end{abstract}

Keywords: Rendang Lokan, Culinary Tourism, Tourism Attraction

\section{INTRODUCTION}

In the past few years, culinary tourism is one of the new types of tourism that is currently popular. There are many television shows and Youtube channels that provide content containing food, whether it's processing or eating food in an interesting and unique way, or posting photos of appetizing food or interesting places to eat. Other the trend is content about eating food, which is popularly known as the mukbang show. This development makes culinary a tourist destination to an area, both local and foreign. Following this trend, tourist destination providers have flocked to develop objects and attractions for culinary tourism in their regions, so tourists are more interested to visit. It is not only developing and making modern types of culinary tourism that adopt from outside, but also new trends developed by millennials.

Many previous study have explore this potential. Some of them explore new potential culinary attraction, and some of them explore already exist culinary 
potentials. Turgarini, D., \& Abdillah, F. (2017) in their research entitled Introducing Aceh Traditional Culinary as Tourist Attractions, the results obtained showed that Aceh has a varied culinary potential and very full featured, yet necessary efforts to familiarization some of food Aceh in the international community. Another thing is that most typical culinary Aceh is presented for ceremonial purposes that have not been commercialized. Other research on culinary as tourism attraction, Agung, I. (2017) entitled Tempeh Juice as Potential Health Support Culinary Tourism showed that promotion of tempeh juice should be done consistently and continuously. The government is expected to be more creative in promoting tempeh juice health culinary.

Emphasizing the authenticity of making traditional culinary delights has a very big opportunity to be developed. This is an advantage for many regions that have a rich culture in the form of food or culinary. Indonesia also does not miss taking advantage of this trend to increase tourist visits to its area. As a country rich in heritage culture of many regions in Indonesia which are famous for their delicious culinary delights, West Sumatra, which is one of the regions in Indonesia, is most famous for its delicious and varied culinary delights.

This fact is well known throughout Indonesia and even abroad. As evidenced by the existence of a special restaurant that has served West Sumatra cuisine for a long time, known as "Nasi Padang", one of its flagship menus, rendang, even crowned by CNN Travel as the most delicious food in the world (food.detik.com, 2017). In 2016 West Sumatra also won the world Best Halal Culinary Destination election (hariansinggalang.co.id, 2016), these facts show the high culinary potential of West Sumatra to be developed as a tourist icon, apart from Padang City as the provincial capital, other areas that exist.

West Sumatra also has a lot of local culinary potentials that are no less delicious than Rendang. One of the areas in West Sumatra that also has several special culinary delights that are thought to have the potential to be developed into a tourist attraction, is Pesisir Selatan. Pesisir Selatan has known as a new marine tourism destination in West Sumatra. A group of beautiful islands known as the Mandeh Region is a destination for marine tourism that is on the rise and has been viral on social media because of its beauty that is similar to the Raja Ampat area of Papua.

Apart from the beautiful nature, Pesisir Selatan also has a delicious and distinctive culinary scene, which, if developed, can not only support tourism in Pesisir Selatan as a souvenir, but also become a tourist attraction itself. One of the most famous culinary delights from Pesisir Selatan is Rendang Lokan, which is a type of rendang made from Lokan, the name for freshwater clams in West Sumatra, the name in other areas is mussels or kijing. Rendang Lokan Pesisir Selatan has long been known in West Sumatra, its unique and unique taste makes many people love this dish. To make Rendang Lokan one of the tourist attractions in the South Coast, it is necessary to do some research first, to see whether Rendang Lokan has the potential as a tourist attraction.

\section{METHODOLOGY}

This research was conducted in Painan, Pesisir Selatan Regency. The research method used in this research is descriptive qualitative, with data collection techniques in the form of interviews and observations, interviews were conducted 
with several producers of Rendang Lokan and their employees and also to several tourists who were shopping there. The above informants were selected using purposive sampling and accidental sampling techniques. The results of this interview were then reinforced by observations which were also carried out directly by visiting the location of the manufacture and sale of Rendang Lokan, observing from how to collect raw materials, the manufacturing process to packaging and sales.

The results of interviews and observations are then processed using data analysis techniques, namely data collection, data reduction, data presentation and the final step is drawing conclusions (Sugiyono, 2017: 246). To present the data, two theories are used, the first is Damanik and Weber's (2016: 13) theory about tourist attraction according to Damanik which states that good tourist attraction is closely related to four things, namely having uniqueness, originality, authenticity, and diversity. It was explained that uniqueness can be interpreted as a combination of rarity and uniqueness inherent in a tourist attraction, Originality reflects authenticity or purity, namely to what extent a product is not contaminated or does not adopt a different value from its original value, Authenticity, which refers to authenticity. The difference with originality, authenticity is more to the level of beauty or cultural exoticism as a tourist attraction. Authenticity is a category of values that combines natural, exotic, and earthy characteristics, and diversity is more towards forms and variations. The second theory used is according to Yoeti in Muljadi (2009: 69) which states that the tourist attraction to be sold must meet three conditions in order to provide satisfaction to tourists / visitors, namely: what can be seen (something to see), what can be done (something to do), what can be bought (something to buy).

\section{RESULTS AND DISCUSSION}

\section{RESULT}

Lokan is the name for freshwater clams for local residents of West Sumatra, countrymen with green clams and oysters, but they have a rather large, blackish shell and they don't taste as good as oysters. Lokan is found in many coastal parts of West Sumatra such as the South Coast and Pariaman. Lokan can be found in muddy river estuaries, on the South Coast Lokan can be found at the mouth of the Indrapura river. How to catch Lokan is by diving approximately 10 meters deep in the mouth of the river and then spreading nets to catch the lokan.

In terms of nutritional value and content, Lokan is rich in protein, contains amino acids and vitamins that are rich in fat soluble (A, E , and $\mathrm{K}$ ), as well as water soluble vitamins (B1, B2, B6, B12, and niacin). In addition, shellfish are the main source of minerals that the body needs, such as iodine (I), iron (Fe), zinc ( $\mathrm{Zn})$, selenium (Se), calcium (Ca), phosphorus (P), potassium (K), flour ( F), and others, shellfish also contain lower fat than beef, which can reach 13.9 grams of fat per 100 grams, clams only contain 1.1 grams per 100 grams. To process Lokan into rendang, the first step is to boil Lokan for +5 minutes then remove from the shell, wash the Lokan using salt water until clean.

The cooking process for Rendang Lokan takes +1 hour, Rendang Lokan can also be cooked mixed with ferns or green beans. The following is a description of the ingredients, spices and steps for making Rendang Lokan, namely: 1 . The 
materials used are: a. Lokan meat - $1 \mathrm{~kg}$ b. Lemongrass - 1 stick c. Coconut milk 2 liters d. Bay leaves -4 pieces 2 . Spices are mashed a. Shallots -4 cloves b. Garlic - 2 cloves c. Ginger - 25 grams d. Ground chilies - 1 tablespoon e. Turmeric - 15 grams f. Ground pepper - 1 teaspoon g. Candlenut - 4 grains $h$. Nutmeg - 1/2 grains i. Galangal / laos - 75 grams j. Salt to taste k. Sufficient sugar if necessary.

The three steps in cooking rendang Lokan are as follows: a. Before cooking, first mix Lokan and ground spices evenly and let stand until the spices are well absorbed. b. Pour 1 liter of coconut milk into the pan, stir and cook until it boils. c. Add the seasoned Lokan to the boiling coconut milk until submerged. d. Add salt to taste. e. Cook over medium heat then add lemongrass and bay leaves. Stir continuously until coconut milk is reduced. $\mathrm{f}$. Next is to add the remaining coconut milk periodically every $100 \mathrm{ml}$. If the coconut milk shrinks, add back $100 \mathrm{ml}$ of coconut milk until it runs out while continuing to stir until cooked.

Rendang Lokan that has been cooked is packaged using special vacuum plastic paper for food, packaged in three variations, namely, $1 \mathrm{Kg}$ for IDR 250,000, $1 / 2 \mathrm{Kg}$ for IDR $125,000,1 / 4 \mathrm{Kg}$ for IDR 55,000. This Rendang Lokan can only last around 2-4 days.

\section{DISCUSSION \\ Uniqueness}

Uniqueness is a combination of rarity and uniqueness inherent in a tourist attraction. As a product that contains a unique tourist attraction owned by Rendang Lokan that cannot be found in other similar foods, namely its unique taste, the combination of the fishy taste of fresh water side dishes with savory and luxurious Minangkabau spices and spices that give impressive pleasure to those who taste it. Based on the results of interviews conducted with several informants, it is concluded that the South Coastal Rendang Lokan Culinary has several uniqueness and characteristics, namely: a. Lokan as a staple ingredient of rendang is rarely found in other areas in West Sumatra. b. Lokan Pesisir Selatan is sweeter than Lokan in other areas. c. Rendang Lokan has a different taste and is more unique than rendang in general.

\section{Originality}

Originality, which reflects authenticity or purity, namely the extent to which a product is not contaminated or does not adopt a different value from the original value. The results of the interview with the Rendang Lokan business owner stated: "The main attraction of Rendang Lokan is the authenticity of the ingredients and spices used, which are still original and natural, the processing method has also been the same since long ago". (Informant 1, 2019). The statement of informant 1 was also corroborated by the six other informants who stated the same thing, so that it can be concluded as follows: a. Rendang Lokan is one of the culinary delights that is known as a typical food from the Pesisir Selatan Regency b. Rendang Lokan is processed still using natural and original ingredients and spices, such as ground spices and spices that are pounded by yourself. c. Rendang Lokan is cooked in the same way from the past until now, it has not been changed or eliminated at all. 


\section{Authenticity}

Authenticity is the beauty or exoticism of culture as a tourist attraction and is a value category that combines natural, exotic, and unpretentiousness. Based on the results of interviews and observations, it is concluded that Rendang Lokan has the following authenticity: a. Rendang Lokan is still processed traditionally, namely by using traditional ingredients and tools such as grinding or pounding spices with traditional tools and cooking using a wood-burning stove. b. The appearance of Rendang Lokan is attractive and the aroma of aromatic spices is appetizing Diversity Diversity in a tourist attraction is more towards the shape and variety. Informant I stated that "Rendang Lokan has two flavors, namely the original Rendang Lokan and a mixture of fern vegetables, the most frequently ordered by buyers, namely the original Rendang Lokan". This statement was reinforced by informants 2, 3 and 4. Informants 5, 6 and 7 who were buyers, also confirmed the above statements. Based on the theory from Damanik and Weber (2006: 13) in Harsana, et.al. (2018) which states that good tourist attraction is related to four things, namely having uniqueness, originality, authenticity, and diversity. So it can be concluded that Rendang Lokan in Pesisir Selatan Regency has the potential as a tourist attraction.

According to Yoeti in Muljadi (2009: 69) the attractiveness to be sold must meet three requirements in order to provide satisfaction to tourists / visitors, namely: what can be seen (Something to see), what can be done (Something to do), what can be purchased (Something to buy). A good tourist attraction must have something that is given to tourists or visitors so that they feel satisfied, one of which is that tourists can see something that they don't see in their area or they don't find in other areas. In visiting a tourist destination, Rendang Lokan as a tourist attraction is expected to fulfill this element.Based on the results of interviews with the Rendang Lokan business owner stated that: "Willing to show tourists who want to see the processing of Rendang Lokan". (Informant 1, 2019) This statement was supported by informants 2,3 and 4 who were also owners and employees of the Rendang Lokan Business, from a tourist point of view, information was also obtained that they were interested in witnessing the process of making rendang lokan firsthand, as stated below: "Interested, because I really want to see the processing of the Rendang Lokan". (Informant 7, 2019) The next element, namely, "What can be done (Something to do)", doing something new that they have never done before. Learning and participating in the process of making Rendang Lokan will be an interesting and memorable experience for tourists, cooking in the traditional way is something that will arouse the curiosity of tourists. This is also supported by the approval of the Rendang Lokan business owner who stated their willingness to involve tourists in the process of making Rendang Lokan, which can be seen in the following interview excerpt: "Tourists or visitors can participate in making the Rendang Lokan". (Informant 1, 2019)

Likewise, the statement from tourists who have bought Rendang Lokan stated: "Willing, because I really want to make the Rendang Lokan". (Informant 6, 2019) The next element is "What can be bought (Something to buy)". The next tourist attraction that can provide satisfaction to tourists, namely buying and feeling something new and unique from the area visited, Rendang Lokan as a product certainly fulfills this element, is supported by good and attractive packaging, so 
Rendang Lokan will become a gift. typical of Pesisir Selatan that will be hunted by tourists visiting this area.

Based on the theory from Yoeti in Muljadi (2009: 69) states that the tourist attraction to be sold must meet three requirements in order to provide satisfaction to tourists / visitors, namely: what can be seen (Something to see), what can be done (Something to do ), and what can be bought (Something to buy), then it can be concluded that the Rendang Lokan has met three requirements regarding the tourist attraction to be sold, it must be able to provide satisfaction. In the previous discussion about things that state that a good tourist attraction is closely related to four things, namely having uniqueness, originality, authenticity, and diversity (Damanik and Weber, 2006: 13) where the results obtained were that Rendang Lokan met the above criteria. as well as the theory from Yoeti in Muljadi (2009: 69) about the tourist attraction to be sold must meet three requirements in order to provide satisfaction to tourists / visitors, namely: what can be seen (Something to see), what can be done (Something to do), and what can be bought (Something to buy). It can be concluded that Rendang Lokan in Pesisir Selatan Regency has the potential to be developed as a culinary tourism attraction.

\section{CONCLUSION}

Based on the explanation of the results of the above research, it can be concluded that Rendang Lokan has the potential to be developed as a tourist attraction, which can be seen from its uniqueness, originality, authenticity, and diversity. Three elements, namely: something to see (something to see), something to do (something to do) and something to buy (something to buy) have been accomplished by it. Rendang Lokan has fulfilled all the above elements. This can be seen from the process to produce delicious and attractive products, tourists participation in preparing and cooking traditional lokan rendang and as a product. typical of Pesisir Selatan which can be a souvenir that tourists can take home.

\section{REFERENCES}

CNN Travel. ( 14/07/2017).Penobatan Rendang Makanan Terlezat di Dunia Pada Tahun 2017 . Di akses 25 Juni 2019, dari http://food.detik.com

Damanik, J \& Weber, H.F. (2006). Perencanaan Ekowisata. Yogyakarta: CV Andi Offset.

Hariansinggalang.co.id. (09/12/2016). Menang di dua kategori Sumbar menjadi destinasi wisata halal dunia. Diundug pada 12 Februari 2020 dari https://hariansinggalang.co.id

Harsana, M., Baiquni, M., Harmayani, E.,\& Widyaningsih, Y.A. (2018). Potensi Makanan Tradisional Kue Kolombeng sebagai daya tarik wisata di Daerah Istimewa Yogyakarta. HEJ (Home Economics Journal). Vol.1, No. 2 Oktober 2018, 40-47

Muljadi A.J. (2009). Kepariwisataan dan Perjalanan. Jakarta: Rajawali Pers Sugiyono. (2017). Metode Penelitian kuantitatif, dan Kualitatif. Bandung: R \& D. 
Turgarini, D., \& Abdillah, F. (2017). INTRODUCING ACEH TRADITIONAL CULINARY AS TOURIST ATTRACTIONS. Journal of Business on Hospitality and Tourism, 2(1), 287-301. doi:http://dx.doi.org/10.22334/jbhost.v2i1.65

Agung, I. (2017). TEMPEH JUICE AS POTENTIAL HEALTH SUPPORT CULINARY TOURISM. Journal of Business on Hospitality and Tourism, 2(1), 347-350. doi:http://dx.doi.org/10.22334/jbhost.v2i1.69 